Reading and Responsibility 
The Frontiers of Theory

Series Editor: Martin McQuillan

The Poetics of Singularity: The Counter-Culturalist Turn in Heidegger, Derrida, Blanchot and the later Gadamer

Timothy Clark

Dream I Tell You

Hélène Cixous

Scandalous Knowledge: Science, Truth, and the Human

Barbara Herrnstein Smith

Geneses, Genealogies, Genres and Genius

Jacques Derrida

Insister of Jacques Derrida

Hélène Cixous

Not Half No End: Militantly Melancholic Essays in Memory of Jacques Derrida

Geoffrey Bennington

Death-Drive: Freudian Hauntings in Literature and Art

Robert Rowland Smith

Of Jews and Animals

Andrew Benjamin

Reading and Responsibility: Deconstruction's Traces

Derek Attridge

The Romantic Predicament

Paul de Man

The Book I Do Not Write

Hélène Cixous

The Paul de Man Notebooks

Paul de Man

Veering: A Theory of Literature

Nicholas Royle 


\section{Reading and Responsibility}

Deconstruction's Traces

Derek Attridge

Edinburgh University Press 


\section{In Memoriam}

JD

(C) Derek Attridge, 2010

Edinburgh University Press Ltd

22 George Square, Edinburgh

www.euppublishing.com

Typeset in Adobe Sabon

by Servis Filmsetting Ltd, Stockport, Cheshire, and

printed and bound in Great Britain by

CPI Antony Rowe, Chippenham and Eastbourne

A CIP record for this book is available from the British Library

ISBN 9780748640089 (hardback)

The right of Derek Attridge

to be identified as author of this work

has been asserted in accordance with

the Copyright, Designs and Patents Act 1988. 